\title{
Water and fire: Vulcano island from 1977 to 1991
}

\author{
MARINO MARTINI \\ Department of Earth Sciences, University of Florence 50121 Florence, Italy
}

(Received November 12, 1992; Accepted May 13, 1993)

\begin{abstract}
The fluctuating behaviour of the volcanic system of Vulcano, which caused changes in chemicalphysical properties of surface manifestations, moderate ground inflation and seismicity, is interpreted to be the result of different contributions of the deep-seated magma (fire) and the near-surface aqueous environment (water). The phenomena observed during the last fifteen years are explained by variations in these two contributions. A factor analysis method was applied to the variation of temperature and chemical composition of fumarolic gases. The results support the model. The absence of major seismic events rules out eruptive activity caused by ascending magma. Significant thermal output from the deeper portions of the system into shallow aquifers, however, caused vaporization of water and, consequently, pressure increase and inflation of the volcano. Landslides in the weakest sectors of the crater slopes can be caused by inflation. The resulting pressure decrease beneath the volcano may have triggered the emission of gases.
\end{abstract}

\section{INTRODUCTION}

Volcanic activity occurs when magma reaches the earth's surface. Magma degassing is considered to be the primary driving force for eruptive phenomenon. Past eruptions are studied in order to understand triggering mechanisms. Inference can then be made about future events. Quantitative modelling of volcanic activity is of great importance for long term forecasting in programs for civil defense. This final goal of volcanological investigations, however, is not yet at hand, so a semiquantitative approach can be attempted only. An example of such an attempt to describe the evolution of activity at Vulcano during the last fifteen years is made here.

\section{Observation Data}

General information about eruptive activity at Vulcano (Fig. 1) was provided by the Greek authors, Homer in the Odyssey and Thucydides in the War of Peloponnesus (VI and V century B.C., respectively). They describe the forges of

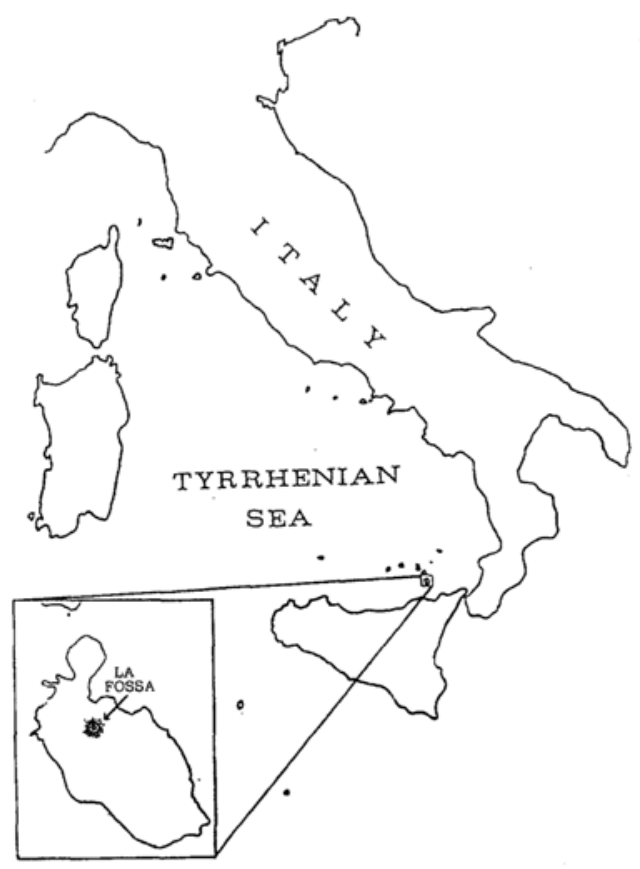

Fig. 1. Location of Vulcano.

the god Vulcano, which emitted smoke during the day and flames at night. Continuous vigorous activity was subsequently reported in 
183 B.C. by the Latin authors Strabo and Pliny the Elder, who were writing during the first decades of the Roman Empire (De Fiore, 1921).

No activity was reported until AD 1444 when a strong eruption occurred. This active stage with fumarolic emissions and episodic explosive phenomena continued until August 1888, when the last eruptive event began (Mercalli, 1883; Mercalli and Silvestri, 1891). Violent explosions with ejection of large bombs were observed up to March 1890 . Subsequently no further eruption has occurred, but significant gas discharge is still continuing with fluctuating intensities.

The island consists of four eruptive centres (Keller, 1980; Frazzetta et al., 1983): ancient Vulcano (composed mainly of trachybasalt and trachyandesite lava flows and pyroclastic deposits), Lentia lava dome (composed of rhyolites, trachytes and latites), "La Fossa" tuff cone (consisting of silicic ash with minor quantities of lava of trachytic to rhyolitic composition) and Vulcanello (composed of tephritic lavas and tuffs). The present fumarolic activities are limited to the main crater "La Fossa".

Systematic investigations on the chemical composition of fumarolic gases and waters from the wells started in 1977 (Martini, 1980; Martini et al., 1980); 202 gas samples and 826 water samples, have been collected at regular intervals and analyzed up to 1991 . Other valuable sets of data obtained in the same area (Carapezza et al. 1981; Cioni and D'Amore, 1984; Tedesco et al.,1991) are limited to shorter observation periods and can only partially supplement the larger data set.

The chemical composition of ground water fluctuates in a time-delayed and smoothed manner in response to volcanic activity (Martini, 1983). Changes in the composition of fumarolic gases are more suitable because they allow inferences to be made about processes that occur in the deep system.

Table 1 shows a simplified set of gas data obtained for a fumarole appeared inside the crater during the "crisis" of 1978. A choice was made to indicate the changes in temperature and chemical composition during the time con-

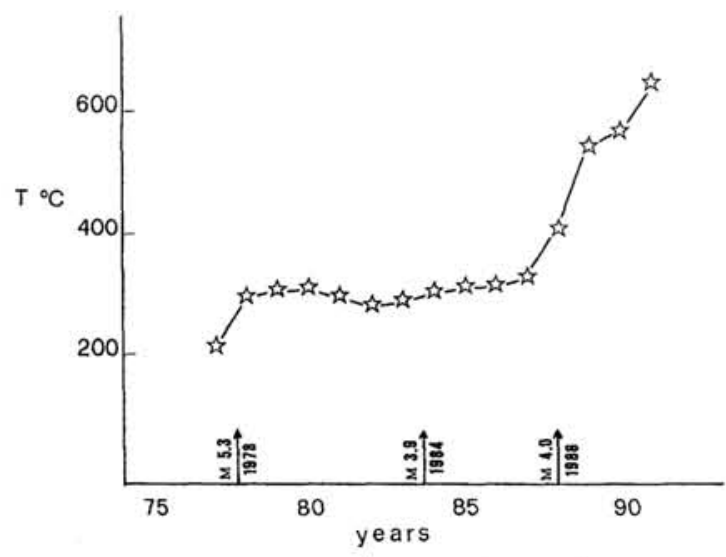

Fig. 2. Variation of maximum fumarolic temperatures observed at Vulcano with time: the arrows indicate significant seismic shocks that occurred in the area.

sidered. All of the data, however, were taken into account during statistical processing and general discussion.

No major volcanic earthquake was observed on the island during the 15 year observation period, which indicates that no magma movement occurred. However, several large tectonic earthquakes did occur in this area; temperature changed in accordance with the earthquakes (Fig. 2) and some modification in gas compositions was noticed as early as December 1977 (Martini et al., 1980). This continued until early 1978 , when a large $(M=5.3)$ seismic event occurred in the area on April 15, 1978. The maximum temperatures of $315^{\circ} \mathrm{C}$ were subsequently recorded in February 1980. A slight decrease in temperature and minor changes in chemical composition of fluids were observed until a seismic swarm ( $M=3.9)$ in January 1984 (Bottari et al., 1984). A large earthquake $(M=5.7)$ occurred 50 $\mathrm{km}$ to the west in May 1980, but it did not interfere with the structure of Vulcano. A progressive change in thermal and chemical outputs, initiation of inflation and new fractures, were recorded in 1987. Another shock occurred in March $1988(M=4.0)$ possibly in response to the overall evolution. The temperature increased up to a maximum of $650^{\circ} \mathrm{C}$ in 1991 .

If the minor changes are neglected, the 
Table 1. Annual mean composition of $F 14$, a representative fumarole, appeared inside the crater of Vulcano in early 1978

\begin{tabular}{|c|c|c|c|c|c|c|c|c|c|c|c|c|c|c|}
\hline & 1978 & 1979 & 1980 & 1981 & 1982 & 1983 & 1984 & 1985 & 1986 & 1987 & 1988 & 1989 & 1990 & 1991 \\
\hline Temp. ${ }^{\circ} \mathrm{C}$ & 154 & 145 & 154 & 112 & 117 & 160 & 193 & 214 & 239 & 273 & 287 & 330 & 361 & 408 \\
\hline $\mathrm{H}_{2} \mathrm{O}$ & 85.6 & 85.4 & 87.9 & 88.3 & 91.6 & 95.3 & 79.8 & 80.7 & 83.3 & 84.7 & 88.9 & 91.4 & 90.8 & 87.4 \\
\hline $\mathrm{CO}_{2}$ & 87.4 & 90.5 & 86.3 & 80.7 & 82.1 & 79.8 & 88.6 & 87.2 & 84.0 & 82.7 & 79.3 & 71.2 & 75.0 & 78.0 \\
\hline $\mathrm{SO}_{2}$ & 6.64 & 5.24 & 6.02 & 4.96 & 3.19 & 3.19 & 4.28 & 5.18 & 5.78 & 5.82 & 6.58 & 8.68 & 7.06 & 8.25 \\
\hline $\mathrm{H}_{2} \mathrm{~S}$ & 0.44 & 0.12 & 0.34 & 1.19 & 2.18 & 4.46 & 2.45 & 3.40 & 4.23 & 5.12 & 7.12 & 9.72 & 8.47 & 6.11 \\
\hline $\mathrm{HCl}$ & 5.20 & 3.95 & 7.18 & 13.0 & 10.8 & 10.4 & 3.50 & 3.54 & 4.89 & 5.17 & 5.86 & 8.10 & 6.62 & 5.02 \\
\hline $\mathrm{HF}$ & 8.0 & 5.5 & 8.0 & 12 & 8.6 & 11 & 10 & 13 & 37 & 129 & 369 & 1065 & 1335 & 1226 \\
\hline B & 89 & 39 & 80 & 80 & 173 & 272 & 95 & 86 & 105 & 55 & 49 & 73 & 97 & 65 \\
\hline $\mathrm{Br}$ & 2.9 & 2.7 & 6.8 & 6.4 & 6.7 & 2.8 & 3.5 & 2.7 & 5.9 & 8.0 & 5.8 & 19 & 11 & 5.9 \\
\hline $\mathrm{NH}_{4}$ & 0.2 & 0.3 & 0.6 & 1.6 & 0.2 & 6.4 & 37 & 16 & 26 & 35 & 21 & 75 & 69 & 63 \\
\hline $\mathrm{H}_{2}$ & na & na & na & na & 14 & 15 & 3.2 & 2.5 & 4.7 & 6.8 & 16 & 40 & 90 & 146 \\
\hline $\mathrm{O}_{2}$ & na & na & na & na & 1.8 & 1.3 & 1.6 & 2.6 & 0.9 & 0.9 & 0.9 & 0.9 & 7.8 & 1.4 \\
\hline $\mathrm{N}_{2}$ & na & na & na & na & 1310 & 787 & 742 & 430 & 670 & 765 & 672 & 753 & 1021 & 884 \\
\hline $\mathrm{CO}$ & na & na & na & na & - & - & - & - & - & 0.1 & 0.1 & 0.2 & 1.2 & 2.7 \\
\hline
\end{tabular}

Values, in volume percent of water and of dry gases, are multiplied by 1000 for $\mathrm{HF}, \mathrm{B}, \mathrm{Br}, \mathrm{NH}_{4}, \mathrm{H}_{2}, \mathrm{O}_{2}, \mathrm{~N}_{2}, \mathrm{CO}, \mathrm{na}=\mathrm{not}$ analyzed, $-=$ below the detection limit (0.05)

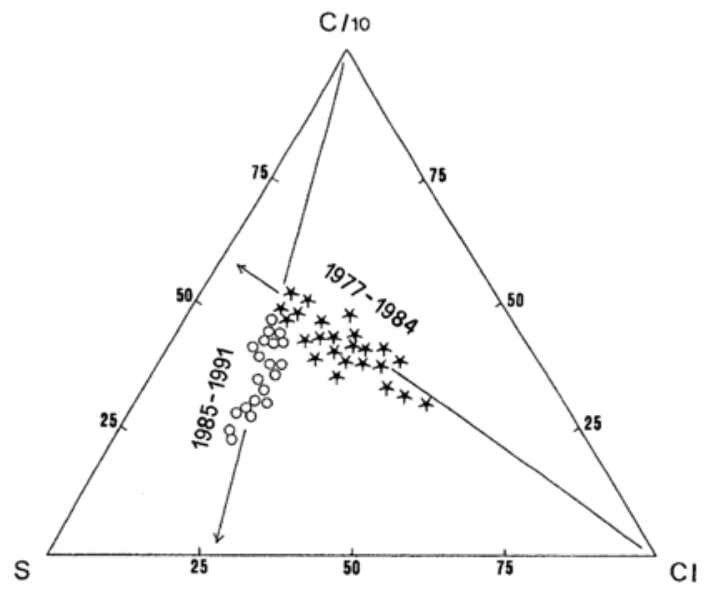

Fig. 3. $\mathrm{C}-\mathrm{S}-\mathrm{Cl}$ diagram for the annual mean composition of different fumaroles; stars: samples collected from 1977 to 1984, circles: samples collected from 1985 to 1991.

history of Vulcano during the last fifteen years is well characterised by change in relative concentrations of carbon dioxide, sulfur species, and hydrogen chloride, in fumarolic gases from 1977 to 1984 , and from 1985 to 1991 (Fig. 3). During the first period, variable contributions of $\mathrm{HCl}$ occurred as the $\mathrm{C} / \mathrm{S}$ ratio remained constant. During the second period the gas compositions are represented by a trend consisting of different contributions of $\mathrm{CO}_{2}$ and an almost constant $\mathrm{S} / \mathrm{HCl}$

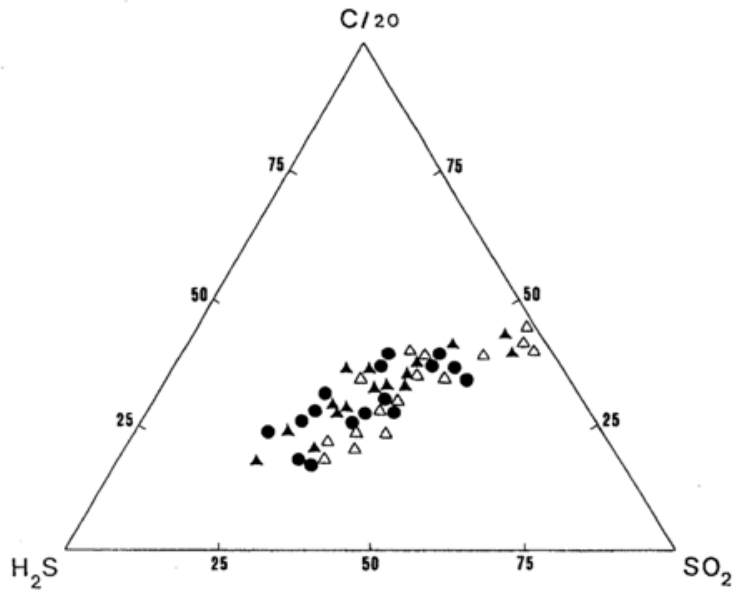

Fig. 4. $\mathrm{C}-\mathrm{H}_{2} \mathrm{~S}-\mathrm{SO}_{2}$ diagram for the annual mean composition of different fumaroles from 1977 to 1991; open triangles: from the inner slope; full triangles: on the rim; circles: from the outer slope.

ratio. Figure 4 shows that the variable $\mathrm{C} / \mathrm{S}$ ratio is mainly due to significant fluctuations of $\mathrm{H}_{2} \mathrm{~S}$ since $\mathrm{CO}_{2} / \mathrm{SO}_{2}$ ratio was constant. The temporal changes in water concentration and the $\mathrm{H}_{2} \mathrm{~S} / \mathrm{CO}_{2}$ ratio coincide (Fig. 5a). The variations of water concentration also correlate well with their $\delta \mathrm{D}$ values (Panichi and Noto, 1992) (Fig. 5b). Significant contributions of an isotopically heavier water, such as seawater, could be considered to have contributed to the evolution of 


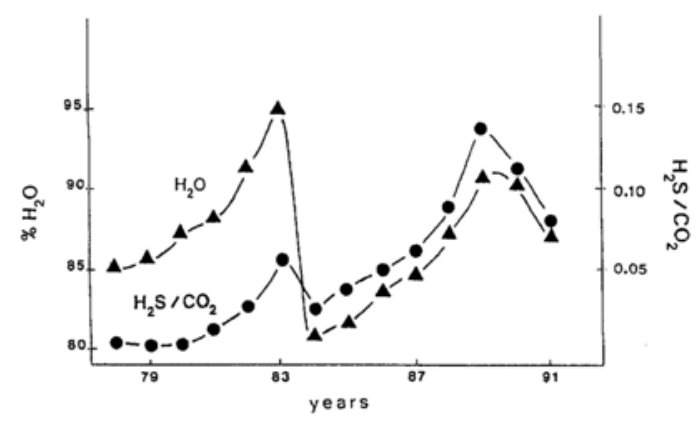

Fig. 5a. Variation of concentrations of $\mathrm{H}_{2} \mathrm{O}$ (triangles) and of the $\mathrm{H}_{2} \mathrm{~S} / \mathrm{CO}_{2}$ ratios (circles) with time.

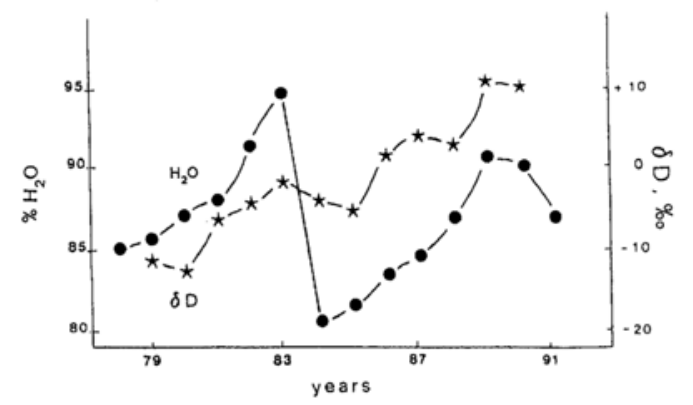

Fig. 5b. Variation of concentrations of $\mathrm{H}_{2} \mathrm{O}$ (circles) and of the $\delta D$ values with time, (stars, from Panichi and Noto, 1992).

the system.

\section{Discussion}

Martini et al. (1980) proposed a model of the volcanic system in which shallow aquifers located between the magma chamber and the surface acted as a "buffer" to the thermal and chemical input. Interpretation of the analytical data is in accordance with their model.

The period from 1977 to mid-1984 appears as mainly characterized by a contribution of isotopically heavy waters with high-chloride content (possibly marine-like brines) to the system as a consequence of changes to the deep structure in response to the stresses culminating during the seismic events of 1978 and 1984. A stronger inflow of magmatic fluids characterised by higher gas/water ratios may have occurred during 1984. An increase in ground water recharge started to occur in 1985.
The changes in the balance of these contributions could also result in different extents of water-gas reaction. Since carbon dioxide is less soluble than hydrogen sulfide (Giggenbach, 1980), an increase in water/gas ratio in the fumaroles should occur together with a decrease of $\mathrm{H}_{2} \mathrm{~S} / \mathrm{CO}_{2}$ ratio. But the opposite trend was observed in the fumaroles located at Vulcano. This implies that an additional input of $\mathrm{H}_{2} \mathrm{~S}$ can overwhelm the effect of its higher solubility. Reactions of acid solutions with elemental sulfur and/or dispersed sulfides, largely available within active volcanic systems, could be responsible for the extra $\mathrm{H}_{2} \mathrm{~S}$ production (Cellini Legittimo and Martini, 1989).

The gas composition and temperature data collected from 1977 to 1991 were processed using a statistical factor analysis procedure (Davis, 1973; Joreskog et al., 1976; Buccianti and Martini, 1990). This permitted an evaluation of the extent to which a minimum number of variables influenced the behaviour of the system studied. Table 2 gives the matrix of variables and factors, as the result of the statistical procedure. If 0.65 is considered as a threshold of significance, the association of factors and variables is shown in Table 3. The meaning of the main factors explaining different extents of the variance of the system is discussed based on these results.

Water is the quantitatively most important component and displays large fluctuations because of different diluting agents in the fumarolic fluids.

High-temperature fumaroles are expected to result from a large contribution of magmatic gases, so that a positive correlation should exist between their concentrations and temperature. However, the existence of the "buffer" aquifer disturbs this simple correlation because it dissolves $\mathrm{CO}_{2}$ and $\mathrm{SO}_{2}$, and an increase in temperature of the fumaroles can occur without a corresponding increase in the concentrations of these gases.

A ground water contribution ("cold" recharge) should produce a decrease in temperature and in concentration of chemical components of fumarolic gases. The concentrations 
Table 2. Result of the statistical factor analysis: matrix of variables and factors

\begin{tabular}{lrrr}
\hline & Factor 1 & Factor 2 & Factor 3 \\
\hline Temperature & 0.74 & 0.05 & -0.27 \\
$\mathrm{H}_{2} \mathrm{O}$ & 0.06 & -0.91 & -0.26 \\
$\mathrm{CO}_{2}$ & -0.15 & 0.83 & 0.01 \\
$\mathrm{H}_{2} \mathrm{~S}$ & 0.77 & 0.25 & -0.08 \\
$\mathrm{SO}_{2}$ & 0.22 & 0.86 & 0.21 \\
$\mathrm{HCl}$ & -0.14 & 0.19 & 0.85 \\
$\mathrm{HF}$ & 0.88 & -0.08 & 0.01 \\
$\mathrm{~B}$ & -0.15 & 0.07 & 0.71 \\
$\mathrm{Br}$ & 0.29 & -0.18 & 0.73 \\
$\mathrm{NH}_{4}$ & 0.53 & -0.16 & 0.32 \\
\hline
\end{tabular}

Table 3. Result of the statistical factor analysis: association of variables and factors

\begin{tabular}{ccc}
\hline Factor & Associated variables & Variance explained \\
\hline 1 & Temperature, $\mathrm{HF}, \mathrm{H}_{2} \mathrm{~S}$ & 0.34 \\
2 & $\mathrm{SO}_{2}, \mathrm{CO}_{2}$ & 0.22 \\
3 & $\mathrm{HCl}, \mathrm{B}, \mathrm{Br}$ & 0.16 \\
\hline
\end{tabular}

of $\mathrm{Cl}, \mathrm{Br}$, and $\mathrm{B}$ in gases, however, can increase if marine-like brines enter fumaroles.

If increased heatflow occurs at the same time as a water contribution ("hot" recharge), $\mathrm{H}_{2} \mathrm{~S}$ and $\mathrm{HF}$ concentrations increase with temperature. The above mentioned rock-water reaction can explain the increase in $\mathrm{H}_{2} \mathrm{~S}$. The influence of temperature on HF concentrations is a common feature of volcanic gases, and has been explained in terms of different degrees of reaction of gas with channel wall (Sugiura et al., 1963; Stoiber and Rose, 1970).

The statistical factor 1 thus corresponds to the species associated with hot recharge, that is to both thermal input and water contribution. Factor 2 is related to "dry" magmatic gases, and factor 3 is related to marine components in shallow aquifers ("cold" recharge). The temporal variation of the scores of the different factors (Fig. 6) indicate an increasing importance of factor 1 from 1985. Factor 2 shows a peak value corresponding to the seismic event of 1984 , while factor 3 displays minor fluctuations. Accordingly, a "cold" recharge appears to be the main feature from 1977 to mid-1984, and "hot" recharge is prevailing feature starting in 1985 .

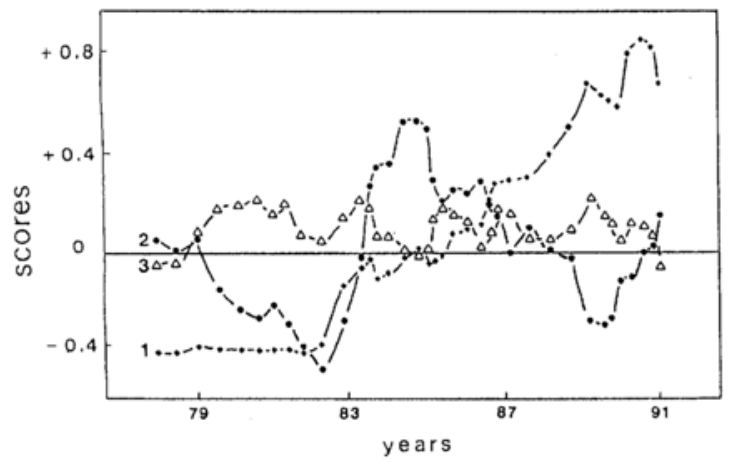

Fig. 6. Variation of the scores of different statistical factors with time (see text).

The seismic shock in 1984 was followed by an increased input of "dry" magmatic gases.

By using the same model, a vapour pressure buildup was indicated in advance of the inflation process observed in the fall of 1987 (Martini, 1986; 1989).

\section{VOLCANOLOGICAL IMPLICATIONS}

Although the last eruption in 1888 led to the introduction of the term "vulcanian", most of the ancient and recent activities at Vulcano show an hydrovolcanic character. According to Frazzetta et al. (1984) four principal eruptive cycles can be distinguished from the different types of deposits observed around the volcano: early wet-surge beds, dry-surge horizons, fall deposits and finally lava flows. These eruptive patterns may be controlled by a decrease in the efficiency of water/magma interaction.

The mode of interaction between magma and water strongly depends on their mass ratios (Sheridan and Wohletz, 1983). No explosion can occur in water dominated systems, lava flows are mainly observed for very low water/magma ratios, and phreatomagmatic events are limited to intermediate conditions.

The evolution of the cycles observed at Vulcano suggests a predominance of magma over water, probably because of aquifers of limited volumes. The high temperature and pressure in magma are not favourable for movement of external water towards the ascending 
magma column. The presence of aquifers located between the magma chamber and the surface seems to provide the necessary condition for triggering phreatomagmatic processes. The occurrence of aquifers near the ascending paths of magmas deserve better attention.

The chemical changes observed in the fumaroles located at Vulcano allow the possibility of the existence of aquifers beneath the crater "La Fossa". The inflation at the crater and the soil creeping are the effects of this water dominated situation. The efficiency of this aqueous "buffer" will be reduced by an increase of heat or insufficient recharge. Since there was no ascending magma body (major volcanic seismic activity was absent), direct interaction between water and fire (magma) did not occur.

Different degrees of vaporization of the aquifer will take place in response to the change in thermal output from magma, and water recharge from aquifers. Progressive ground inflation is probably the only significant phenomenon expected at the surface. An extended inflation, however, can seriously affect the stability of the slopes, so large landslides can occur. Landslides will cause further decompression of the shallow portions of the system and gas release could follow.

Acknowledgments-This work was supported by C.N.R., Centro di Studio per la Minerogenesi e la Geochimica Applicata.

\section{REFERENCES}

Bottari, A., Caccamo, D., Falsaperla, S. and Neri, G. (1984) Analisi preliminare dell'attivita' sismica con origine nell'area di Vulcano durante il primo semestre 1984. Open-File Rep., I.I.V., Catania.

Buccianti, A. and Martini, M. (1990) Analisi statistica multidimensionale: un esempio di applicazione, nel quadro della sorveglianza delle aree vulcaniche attive italiane. Atti del secondo Workshop "Informatica e Scienze della Terra", Sarnano, 34-43.

Carapezza, M., Nuccio, M. and Valenza, M. (1981) Genesis and evolution of the fumaroles of Vulcano (Aeolian Islands, Italy); a geochemical model. Bull. Volcanol. 44, 548-563.

Cellini Legittimo, P. and Martini, M. (1989) The ecological significance of the coexistence of sulphur dioxide and hydrogen sulphide in volcanic fumaroles. Chemistry and Ecology 4, 15-20.

Cioni, R. and D'Amore, F., (1984) A genetic model for the crater fumaroles of Vulcano Island (Sicily, Italy). Geothermics 13, 375-384.

Davis, J. C. (1973) Statistics and data analysis in geology. Wiley and Sons, New York, $543 \mathrm{pp}$.

De Fiore, O. (1921) Le eruzioni sottomarine, i fenomeni vulcanici secondari nelle Eolie e le eruzioni storiche di Lipari. Zeit. Vulkanologie 6, 114154.

Frazzetta, G., La Volpe, L. and Sheridan, M. (1983) Evolution of the Fossa cone, Vulcano. J. Volcanol. Geotherm. Res. 17, 329-360.

Frazzetta, G., Gillot, P. Y., La Volpe, L. and Sheridan, M. F. (1984) Volcanic hazard at Fossa of Vulcano: data from the last 6000 years. Bull. Volcanol. 47, 105-124.

Giggenbach, W. F. (1980) Geothermal gas equilibria. Geochim. Cosmochim. Acta 44, 2021-2032.

Joreskog, K. G., Klovan, J. E. and Rayment, R. A. (1976) Geologic factor analysis. Elsevier Publishing Co., Amsterdam, 178 pp.

Keller, J. (1980) The island of Vulcano. Rend. Soc. It. Min. Petrol. 36, 369-414.

Martini, M. (1980) Geochemical survey on the phreatic waters of Vulcano (Aeolian Islands, Italy). Bull. Volcanol. 43, 265-274.

Martini, M., Piccardi, G., Cellini Legittimo, P. (1980) Geochemical surveillance of active volcanoes: data on the fumaroles of Vulcano (Aeolian Islands, Italy). Bull. Volcanol. 43, 255-263.

Martini, M. (1983) Variations in surface manifestations at Vulcano (Aeolian Islands, Italy) as a possible evidence of deep processes. Bull. Volcanol. 46, 83-86.

Martini, M. (1986) International Volcanological Congress, New Zealand, Abstracts volume, 261.

Martini, M. (1989) The forecasting significance of chemical indicators in areas of quiescent volcanism: examples from Vulcano and Phlegrean Fields (Italy), Volcanic Hazards (S. H. Latter, ed.), Springer, Berlin.

Mercalli, G. (1883) Vulcani e fenomeni vulcanici in Italia. Milano.

Mercalli, G. and Silvestri, O. (1891) Le eruzioni dell'isola di Vulcano incominciate il 3 Agosto 1888 e terminate il 22 Marzo 1890. Atti Uff. Centr. Meteorologia e Geodinamica X, 1-213.

Panichi, C. and Noto, P. (1992) Isotopic and chemical composition of water, steam, and gas samples of the natural manifestations of the island of Vulcano (Aeolian arc, Italy) Acta Vulcanologica 2, 297-312.

Sheridan, M. and Wohletz, K. H. (1983) 
Hydrovolcanism: basic considerations and review. J. Volcanol. Geotherm. Res. 17, 1-29.

Sugiura, T., Mizutani, Y. and Oana, S (1963) Fluorine, chlorine. bromine and iodine in volcanic gases. J. Earth Sci. Nagoya Univ. 11, 272-278.

Stoiber, R. E. and Rose W. I. (1970) The geochemistry of Central-American volcanic gas con- densates. Geol. Soc. Am. Bull. 81, 2891-2912.

Tedesco, D., Toutain, J. P., Allard, P. and Losno, R. (1991) Chemical variations in fumarolic gases at Vulcano Island (Southern Italy): seasonal and volcanic effects. J. Volcanol. Geotherm. Res. 45, 325-344. 